\title{
JUBILEUSZ 70-LECIA PROFESOR DOBROCHNY JANKOWSKIEJ
}

\author{
IN HONOUR OF ASSOCIATE \\ PROFESSOR DOBROCHNA JANKOWSKA - \\ ON HER $70^{\mathrm{TH}}$ BIRTHDAY
}

\author{
Jacek Wierzbicki \\ Instytut Prahistorii, Uniwersytet im. Adama Mickiewicza \\ ul. Umultowska 89D, 61-614 Poznań, Poland \\ jacwierz@amu.edu.pl
}

W maju 2014 r. swe 70. urodziny obchodziła prof. dr hab. Dobrochna Jankowska, związana - jak się dziś wydaje, „od zawsze” - z Uniwersytetem im. Adama Mickiewicza w Poznaniu. Jednak urodziła się w Szczecinku i tam uzyskała maturę w liceum ogólnokształcącym. Jej łączność z poznańskim środowiskiem archeologicznym datuje się dokładnie od 15 września 1962 r., kiedy to rozpoczęła studia w ówczesnej Katedrze Archeologii Prahistorycznej i Wczesnośredniowiecznej. Ukończyła je 1 czerwca 1967 r. obroną pracy magisterskiej Wczesnośredniowieczne osady typu wiejskiego na Nizinie Wielkopolskiej, która kilka lat później ukazała się drukiem (Jankowska 1971). Był to gorący czas badań nad początkami państwa polskiego, związanych z obchodami jego milenium, dlatego też tematyką wczesnego średniowiecza interesowali się wtedy wszyscy absolwenci (pięć osób) archeologii tego rocznika.

D. Jankowska od samego początku uczestniczyła w programach badawczych prowadzonych przez Katedrę Archeologii, a współpracy tej nie przerwała nawet podczas trzech lat pracy na stanowisku kierownika Muzeum Regionalnego w Szczecinku (od 1 stycznia 1967 do 31 grudnia 1969 r.). W muzeum tym utworzyła dział archeologiczny, a jednocześnie we współpracy z Konserwatorem Zabytków w Koszalinie prowadziła na Pomorzu Środkowym liczne samodzielne prace wykopaliskowe typu ratowniczego, na stanowiskach pochodzących z różnych okresów pradziejów i wczesnego średniowiecza (Jankowska 1967, 1968, 1969).

Gdy jednak 1 listopada 1969 r. rozpoczynała swoją pracę na UAM na stanowisku asystenta, a była to jedna z pierwszych decyzji personalnych prof. dr. hab. Jana 
Żaka, który kierownikiem katedry został we wrześniu tego roku, musiała porzucić średniowiecze na rzecz epoki kamienia. Decyzja o Jej zatrudnieniu została podjęta, jak można przypuszczać, zapewne z udziałem Kazimierza Siuchnińskiego (Jankowska 2005a, s. 9), będącego wcześniej opiekunem Jej roku, z którym jako studentka wyjeżdżała na badania terenowe związane $\mathrm{z}$ weryfikacją stanowisk neolitycznych na Pomorzu (ryc. 1). To właśnie w ich trakcie 1 maja 1963 r. wzięła udział w powierzchniowo-sondażowych badaniach na terenie rozległej, wielofazowej osady kultury pucharów lejkowatych na stanowisku 4 w Poganicach, pow. słupski, obecnie kojarzonej przede wszystkim z Jej nazwiskiem.

Nic więc dziwnego, że w 1970 r., już jako asystent (a od sierpnia 1972 starszy asystent), D. Jankowska zaczęła prowadzić (31 lipca) niewielkie rozpoznawcze ba-

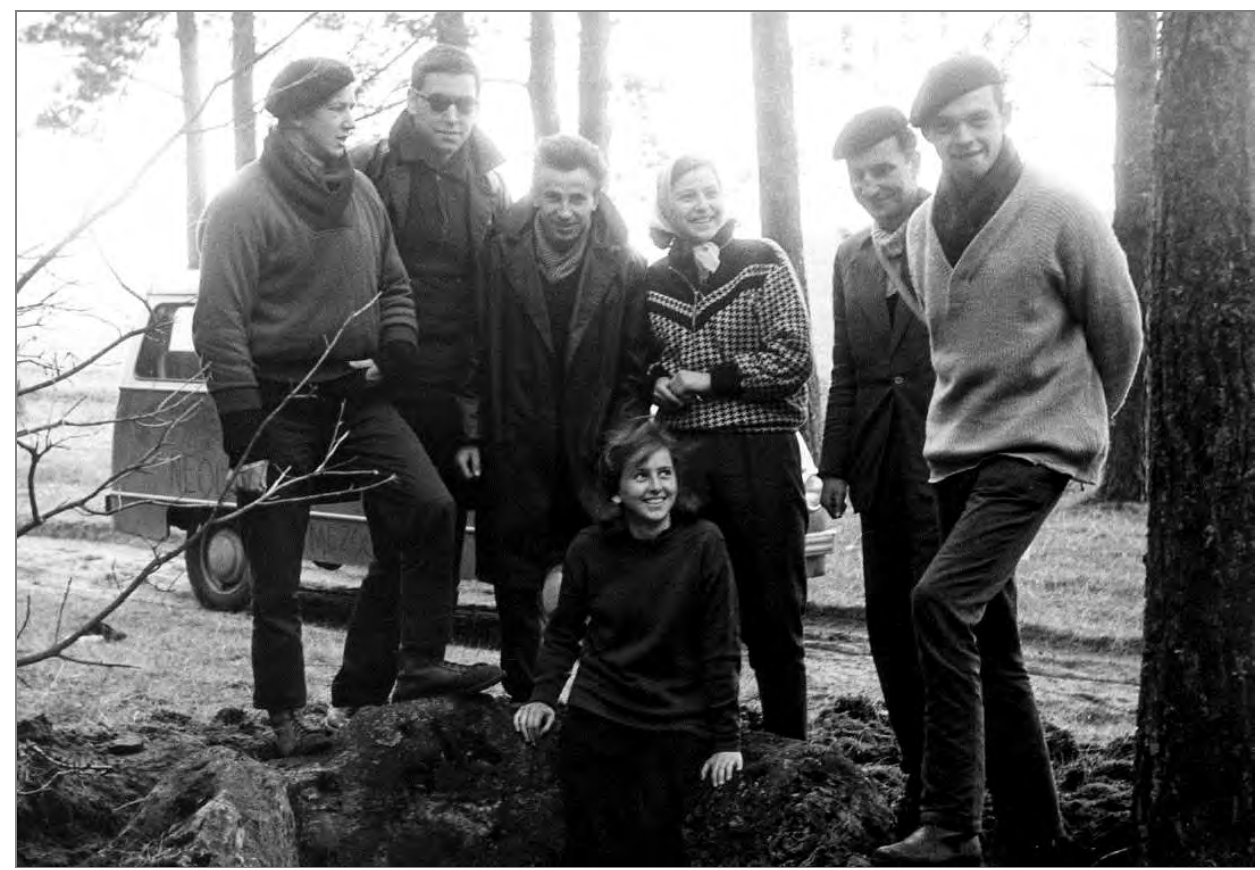

Ryc. 1. Wiosna (kwiecień/maj) 1963 r. - Zagórki, pow. słupski, stan. 1, grób 1. Ekipa Katedry Archeologii pod kierunkiem Kazimierza Siuchnińskiego w czasie badań weryfikacyjnych stanowisk neolitycznych

Od lewej: Sławomir Miernik, Gerard Wilke, Wojciech Skrzypek, Dobrochna Jankowska (wtedy studentka I roku), Kazimierz Siuchniński i Wiesław Popko. W komorze grobowej stoi Wanda Iżyłkowska

Fig. 1. Spring (April/May) 1963 - Zagórki, Słupsk county, site 1, grave 1. Expedition of the Chair of Archaeology, led by Kazimierz Siuchniński, during the verification campaign of the Neolithic sites

From left to right: Sławomir Miernik, Gerard Wilke, Wojciech Skrzypek, Dobrochna Jankowska (at the time the 1st-year student), Kazimierz Siuchniński and Wiesław Popko. Standing in the grave chamber 
dania sondażowe w Poganicach (ryc. 2), które na większą skalę kontynuowała w kolejnych latach. Prace wykopaliskowe w tym miejscu, wyjątkowym w skali nie tylko Pomorza, lecz także całego Niżu Polskiego, trwały aż do 1991 r. Do czasu ich rozpoczęcia obszary Pomorza Środkowego stanowiły właściwie białą plamę pod względem rozpoznania archeologicznego epoki kamienia. Można się było jedynie domyślać, że tworzyły one w okresie neolitu odrębną strefę silnie związaną z basenem Bałtyku. Już pierwsze wyniki badań terenowych potwierdziły te przypuszczenia.

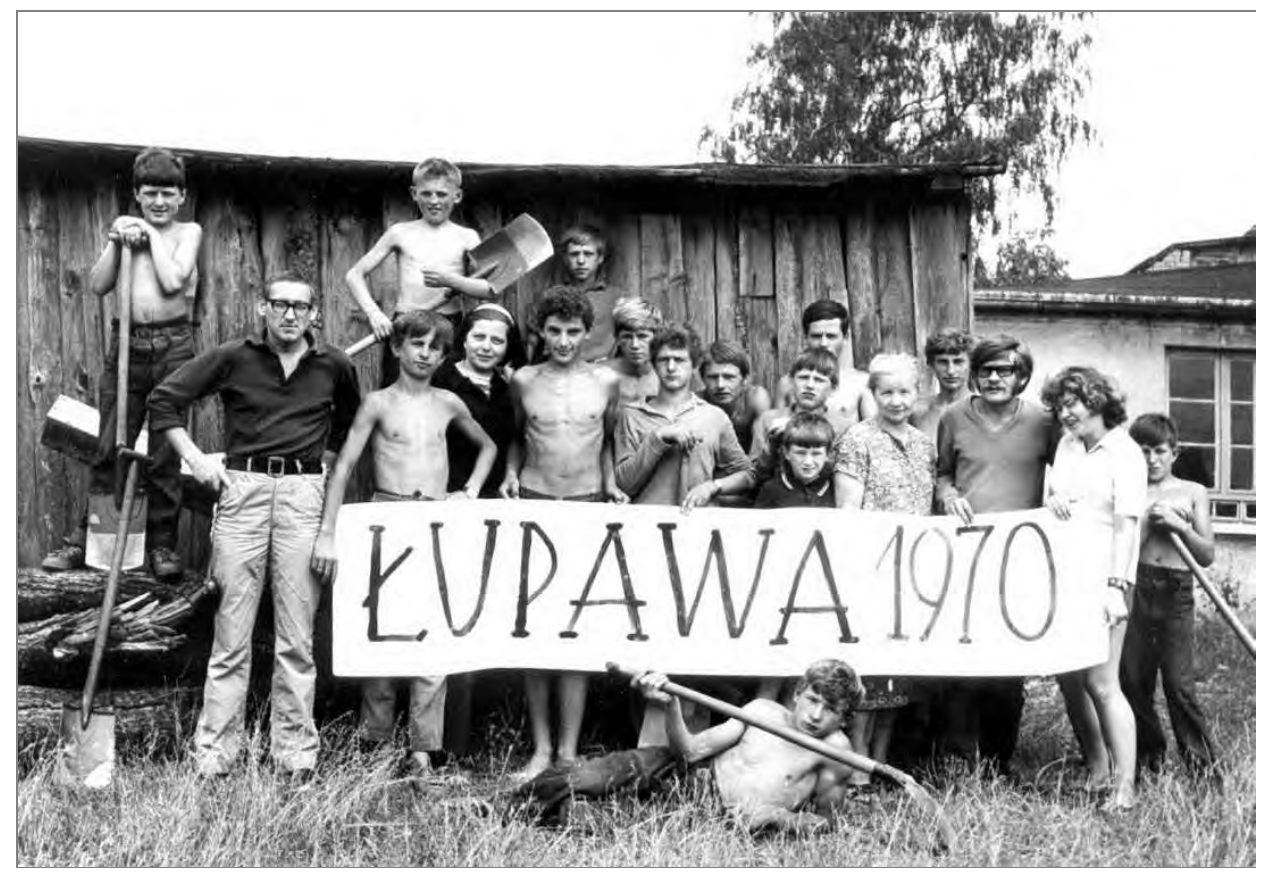

Ryc. 2. Lipiec 1970 r. - pierwszy skład Ekspedycji Łupawskiej zgromadzony na podwórku przed bazą Od lewej: Franciszek Lachowicz, Dobrochna Jankowska, pomiędzy właścicielkami domu stoi Alfred Szułdrzyński, a wokół pracująca na wykopaliskach liczna grupa młodzieży z Łupawy i okolic

Fig. 2. July 1970 - the first lineup of the Lupawa expedition gathered outside in front of the dormitory From left to right: Franciszek Lachowicz, Dobrochna Jankowska, Alfred Szułdrzyński standing between the owners of the house, all around a big group of teenagers from Łupawa and vicinity working on excavations

D. Jankowska potrafiła w całej pełni dostrzec wartość dokonanych przez siebie odkryć. Dlatego też z dużą energią przystąpiła do nadania swoim badaniom większego rozmachu, dążąc do możliwie najpełniejszego rozpoznania kompleksu osadniczego ulokowanego w środkowym dorzeczu Łupawy, konsekwentnie rozbudowując przyjęty a priori program. Dlatego pracami wykopaliskowymi objęte zostały sąsia- 
dujące z osadą w Poganicach cmentarzyska megalityczne na stanowiskach 15 i 18 w Łupawie, pow. słupski, eksplorowane kolejno w latach 1971-1972 i 1973-1977. Spowodowało to, że tutaj przeniósł się na wiele lat punkt ciężkości w badaniach nad kulturą pucharów lejkowatych na Pomorzu. Do dziś jest to najlepiej zbadany pod tym względem mikroregion na Pomorzu.

Specyfikę kulturową dorzecza środkowej Łupawy Jubilatka sygnalizowała w wielu publikacjach już od początku badań terenowych (Jankowska 1973, 1974, 1975a, 1975b, 1976, 1977; Jankowska, Kośko 1974; Jankowska i in. 1979). Podsumowanie zawarła jednak w dysertacji doktorskiej: Grupa tupawska kultury pucharów lejkowa-

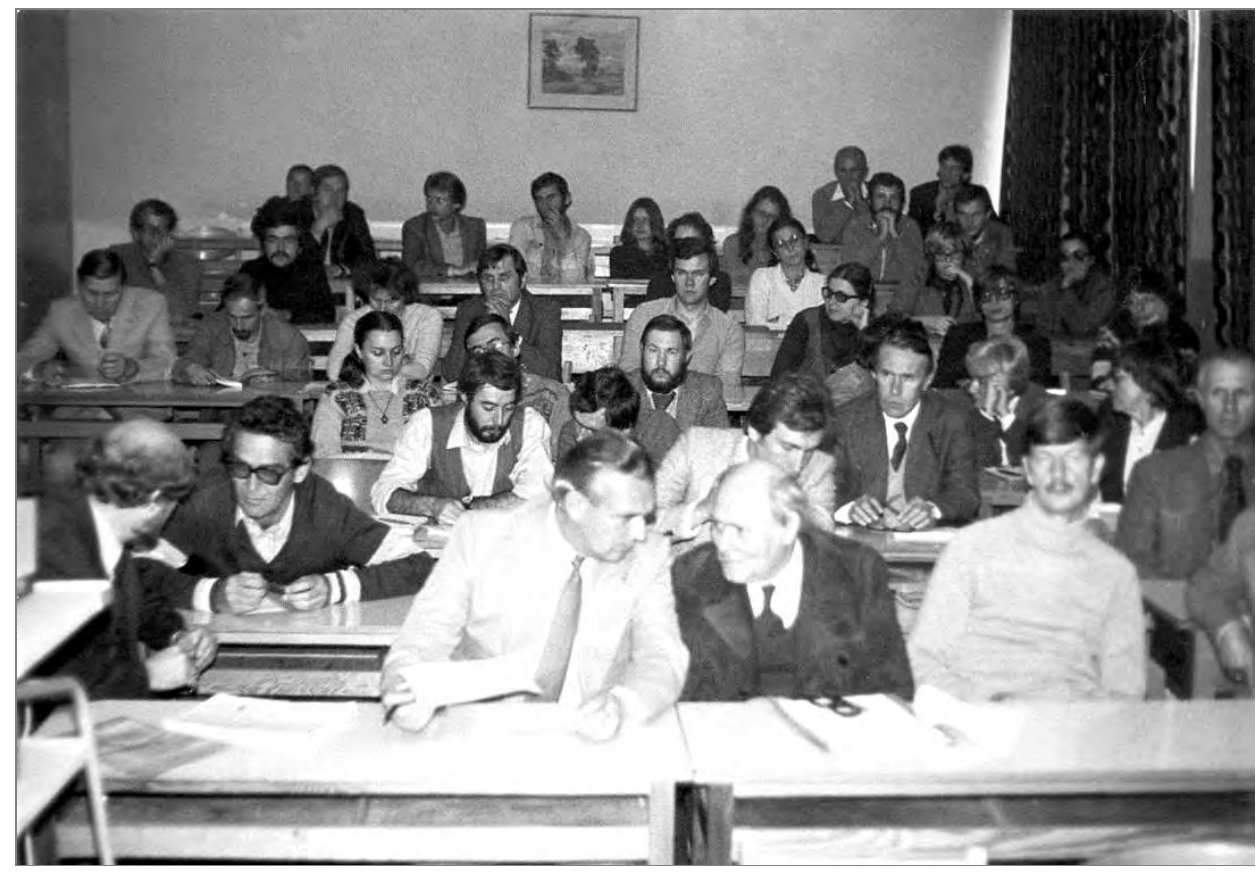

Ryc. 3. Wrzesień 1981 r. - sala Wyższej Szkoły Pedagogicznej w Słupsku w czasie obrad konferencji „Problemy epoki kamienia na Pomorzu”

Na zdjęciu widoczni są m.in.: Dobrochna Jankowska, Zbigniew Bagniewski, Bogdan Balcer, Krzysztof Cyrek, Lucyna Domańska, Olgierd Felczak, Bolesław Ginter, Krzysztof Gorczyca, Ryszard Grygiel, Jan Gurba, Andrzej Kempisty, Elżbieta Kempisty, Ryszard Kirkowski, Michał Kobusiewicz, Zbigniew Kobyliński, Danuta Król, Stefan Karol Kozłowski, Stanisław Kukawka, Elżbieta Majchrzak, Edward

Pudełko, Jacek Wierzbicki, Tadeusz Wiślański i Włodzimierz Wojciechowski (fot. T. Malinowski)

Fig. 3. September 1981 - the lecture hall of the High School of Pedagogy in Stupsk during the conference "Problems of the Stone Age in Pomerania"

In the photo (among others): Dobrochna Jankowska, Zbigniew Bagniewski, Bogdan Balcer, Krzysztof Cyrek, Lucyna Domańska, Olgierd Felczak, Bolesław Ginter, Krzysztof Gorczyca, Ryszard Grygiel, Jan Gurba, Andrzej Kempisty, Elżbieta Kempisty, Ryszard Kirkowski, Michał Kobusiewicz, Zbigniew Kobyliński, Danuta Król, Stefan Karol Kozłowski, Stanisław Kukawka, Elżbieta Majchrzak, Edward Pudełko, Jacek Wierzbicki, Tadeusz Wiślański and Włodzimierz Wojciechowski (photo by T. Malinowski) 
tych, obronionej 16 maja 1977 r., a efektem tego było przejście D. Jankowskiej od 1 października 1977 r. na stanowisko adiunkta.

Praca ta ukazała się drukiem trzy lata później, pod nieco zmodyfikowanym tytułem: Kultura pucharów lejkowatych na Pomorzu Środkowym. Grupa tupawska (Jankowska 1980a). Autorka wykazała w niej odrębność i oryginalność badanego zjawiska kulturowego, określonego przez nią mianem grupy łupawskiej kultury pucharów lejkowatych, które przedstawiła na szeroko zakreślonym tle grup wschodniej i północnej. Ustaliła też jego pozycję chronologiczną i genezę oraz powiązania z innymi grupami, a w szczególności zaproponowała przekonywające wyjaśnienie obecności na Pomorzu Środkowym znacznej ilości widocznych w stylistyce i technologii ceramiki cech pochodzenia północnoniemieckiego i skandynawskiego. Ponadto przedstawiła wiele istotnych zagadnień związanych ze strukturą gospodarczo-społeczną wyróżnionego przez siebie ugrupowania. Wnioski w niej zawarte w zasadniczym zarysie do dziś nie straciły na aktualności, a co najważniejsze: wyróżnienie nowej jednostki kulturowej spotkało się z powszechną akceptacją wśród badaczy problematyki neolitu. Dało się to zauważyć już podczas pierwszej prezentacji tych ustaleń przed dużym gronem specjalistów od epoki kamienia, co miało miejsce we wrześniu 1981 r. podczas odbywającej się w Słupsku konferencji „Problemy epoki kamienia na Pomorzu" (ryc. 3).

Dzięki tym rezultatom sławę i markę uzyskała również Łupawska Ekspedycja Archeologiczna, której twórcą i kierownikiem była D. Jankowska, choć ze względów formalnych początkowo firmował ją swym nazwiskiem J. Żak. W tych pierwszych latach ukształtował się też w miarę stały skład ekspedycji, której trzon stanowiły takie osoby, jak np. Franciszek Lachowicz i Alfred Szułdrzyński, a nieco później studenci o barwnych osobowościach: Krzysztof Gorczyca, Andrzej Weber i Marek Cwetsch. Ci drudzy jednak naturalną koleją rzeczy przychodzą i po ukończeniu nauki odchodzą. W życiu Ekspedycji momentem przełomowym okazał się rok 1978, kiedy to latem na praktyki wykopaliskowe do Łupawy przyjechali sami początkujący, debiutujący na Pomorzu studenci I i II roku. Byłem wśród nich, choć wtedy do Łupawy trafiłem po raz drugi.

Mój pierwszy kontakt z Ekspedycją Łupawską miał miejsce w październiku 1977 r., gdy dwa tygodnie po rozpoczęciu studiów w ówczesnej Katedrze Archeologii zgłosiłem się wraz z innymi osobami z I roku na badania powierzchniowe, choć wtedy jeszcze nazwa Łupawa nic mi nie mówiła, podobnie jak niewiele rozumiałem z celów tej wyprawy (ryc. 4). Teraz już wiem, że ten wyjazd był początkiem długiej drogi, zawodowej i życiowej, którą podążam już prawie 40 lat. Od tamtego pamiętnego dla mnie października uczestniczyłem w zasadzie we wszystkich przedsięwzięciach terenowych Ekspedycji Łupawskiej, przez pierwszych kilka lat wraz z D. Jankowską, później także już bez niej. Tylko w czasie moich studiów spędziłem $\mathrm{w}$ Łupawie ponad 10 wspaniałych miesięcy w towarzystwie niezapomnianych (z różnych zresztą względów) ludzi uczestniczących w tych niezwykłych badaniach 


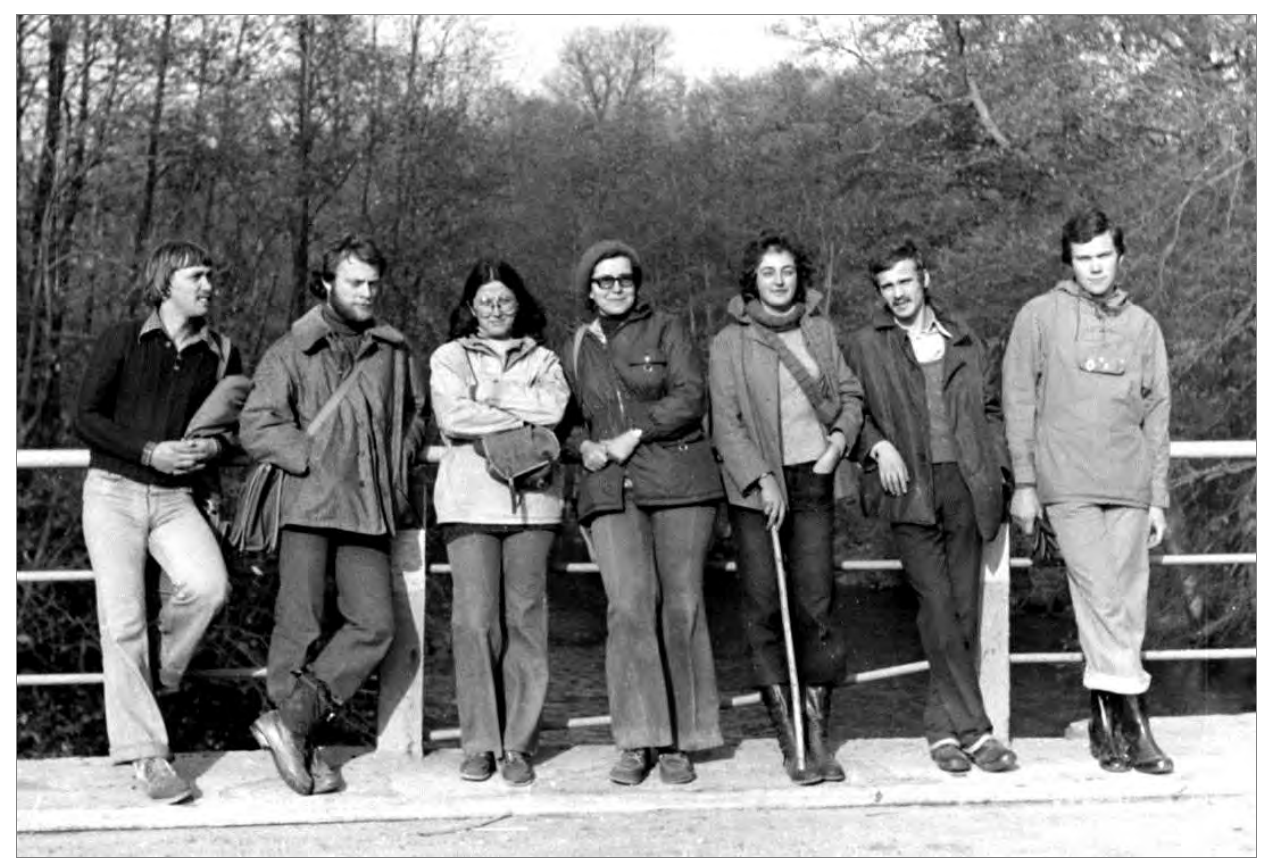

Ryc. 4. Październik 1977 r. - Ekspedycja Łupawska w odnowionym składzie czeka na wymarsz na badania powierzchniowe w Łupawie, na moście nad rzeką o tej samej nazwie

Od lewej: Mariusz Foterek, Andrzej Weber, Elżbieta Majchrzak, Dobrochna Jankowska oraz troje studentów I roku: Katarzyna Szurkowska, Paweł Politowicz i Jacek Wierzbicki (fot. M. Rubnikowicz)

Fig. 4. October 1977 - the Łupawa Expedition in renewed lineup waiting ready to begin field-walking in Lupawa, on the bridge over the river also named Łupawa

From left to right: Mariusz Foterek, Andrzej Weber, Elżbieta Majchrzak, Dobrochna Jankowska with three 1st-year students: Katarzyna Szurkowska, Paweł Politowicz and Jacek Wierzbicki (photo by M. Rubnikowicz)

archeologicznych, zarówno podczas wiosenno-jesiennych badań powierzchniowych, jak i prac wykopaliskowych na cmentarzyskach megalitycznych w Lupawie oraz osadzie poganickiej.

Tamten sezon wykopaliskowy latem 1978 r. był jednak, jak sądzę, bardzo trudny przede wszystkim dla dzisiejszej Jubilatki, jako że została pozbawiona wszystkich swoich wcześniejszych współpracowników, którzy byli też Jej wypróbowanymi przyjaciółmi, a zamiast nich pojawiliśmy się my - młodzi i nieopierzeni. Pomiędzy Nią a nami powstał dystans, nieznany w Łupawie poprzednio, choć zrozumiały z powodu różnicy wieku, doświadczenia i pozycji naukowej. Od tego czasu nic już nie było takie samo.

Pomimo to badania wykopaliskowe ruszyły, i to od razu na czterech frontach, w trzech miejscach oddalonych od siebie o kilka kilometrów: kontynuowano prace na osadzie w Poganicach, a rozpoczęto eksplorację grobowców megalitycznych oraz 
kurhanów kultury łużyckiej w Łupawie stan. 2 (1978-1981), a ponadto wystartowały badania na odkrytym jesienią 1977 r. grodzisku wczesnośredniowiecznym w Łupawie, stan. 36 (1978-1979)! W kolejnych sezonach doszły jeszcze sąsiednie cmentarzyska megalityczne na stanowiskach 2a (1980-1983) i 27 (1982-1983). Zostaliśmy więc jako studenci wrzuceni na głęboką wodę i od początku byliśmy zmuszeni do rozwijania samodzielności, za co teraz jestem dostojnej Jubilatce głęboko wdzięczny.

Warunki, w jakich wtedy pracowaliśmy i mieszkaliśmy w Łupawie, były (w porównaniu $\mathrm{z}$ obecnymi standardami) więcej niż skromne: dużo pracy, mało snu, do tego nadmierne zatłoczenie pomieszczeń, które służyły jednocześnie za miejsce opracowywania dokumentacji i inwentaryzacji materiałów oraz jadalnię i sypialnię. Sytuacja ta wywoływała sporo konfliktów, przez co często bywaliśmy poróżnieni przez jakieś głupstwa. I wtedy uwidaczniała się jedna $\mathrm{z}$ ważnych zalet $\mathrm{D}$. Jankowskiej - jak nikt potrafiła niepostrzeżenie załagodzić każdy kryzys i na nowo scementować swój zespół. W dodatku studentów-praktykantów nie traktowała nigdy z góry, jako przymusowych wyrobników i darmowej siły roboczej, ale jak partnerów - i to zarówno podczas przedsięwzięć terenowych, jak i w czasie dyskusji czy prac gabinetowych związanych z analizą pozyskanych materiałów. Nigdy też nie uważała wyników tych badań za swoją własność, a chętnie dzieliła się nimi ze swoimi współpracownikami, jakim i ja się czułem już w czasie moich pierwszych praktyk wykopaliskowych. Powstało dzięki temu wiele udanych prac magisterskich, z których część doczekała się nawet publikacji (Indycka, Wierzbicki 1993; Pankowski 1990; Świderski, Wierzbicki 1990; Weber 1983; Wierzbicki 1992); inne D. Jankowska wykorzystywała w różnych swoich opracowaniach (Jankowska 2003b).

Poza badaniami terenowymi i pracą naukową Jubilatka z zaangażowaniem zajmowała się też dydaktyką. Już na samym początku zatrudnienia na Uniwersytecie zapoznała się z podstawami pedagogiki szkoły wyższej w Instytucie Nowych Technik Nauczania UAM, a epizod ten zaowocował nawet publikacją opracowania poświęconego znaczeniu archeologicznej praktyki terenowej (Jankowska 1972). W 1970 r. była komendantką studenckiego hufca pracy, a następnie kilka razy opiekunem roku i kuratorem (opiekunem) Koła Naukowego Studentów Archeologii. W 1977 r. z okazji 50-lecia Koła zorganizowała (wraz z jego członkami) V Międzynarodowy Zjazd Studentów Archeologii. Odbył się on w dniach od 25 do 30 kwietnia $\mathrm{w}$ Złotowie, a przybyli tam studenci z uczelni polskich oraz z Czechosłowacji, Węgier, NRD, Austrii i Norwegii, co na tamte czasy było dużym wydarzeniem. Od roku akademickiego 1978/1979 D. Jankowska była pełnomocnikiem Dziekana ds. stypendialnych (studenckich spraw bytowych).

Lata 70. i pierwsza połowa lat 80 . XX w. były okresem szczytowej aktywności terenowej dzisiejszej Jubilatki, która nie ograniczała się tylko do stanowisk położonych w rejonie środkowego dorzecza Łupawy. D. Jankowska nie zaniedbywała też swej pierwszej archeologicznej pasji, czyli średniowiecza, podejmując - poza grodziskiem w Łupawie — również badania wykopaliskowe wczesnośredniowiecznej 
osady produkcyjnej w Wojnowicach, pow. leszczyński, stan. 2 (Jankowska 1980b), nakładającej się na wcześniejsze cmentarzysko z okresu wpływów rzymskich (badania w latach 1977-1980). Interesowały Ją też starsze okresy epoki kamienia, dlatego z dużą energią podjęła się rozpoznania schyłkowopaleolitycznych i mezolitycznych obozowisk nad jeziorem Świdwie w Bolkowie, pow. policki, odkrytych przypadkowo w 1980 r., a badanych wykopaliskowo aż do 1985 r. (Jankowska 1984).

Trudno wręcz uwierzyć, że potrafiła pogodzić to wszystko z pracą naukową, bo przecież nie zaniechała wypowiadania się w kwestiach ważnych dla poznania neolitu na Pomorzu, związanych z kulturami pucharów lejkowatych, amfor kulistych i ceramiki sznurowej, czy to podczas konferencji naukowych (np. w Rydzynie: Kultura pucharów lejkowatych w Polsce, 23-25 października 1979, lub w Szlezwiku: Die frühneolithische Trichterbecherkultur, 4-7 marca 1985), czy też w publikacjach (Jankowska 1981a, 1983, 1985). Jednocześnie D. Jankowska, choć nieco uwolniona od ciężaru związanego z organizacją kolejnych ekspedycji wykopaliskowych, została obarczona odpowiedzialnymi obowiązkami w Instytucie Prahistorii. W latach 1984-1990 przez dwie kadencje pełniła w Instytucie funkcję wicedyrektora ds. studenckich. Na tym stanowisku zajmowała się całokształtem procesu dydaktycznego. Była autorką kilku wersji realizowanych programów studiów archeologicznych. Dydaktyka i praktyki studenckie zawsze znajdowały się w centrum Jej zainteresowań problematyka ta była Jej bliska od samego początku pracy na Uniwersytecie. Za swą działalność dydaktyczną i naukową D. Jankowska dwukrotnie otrzymywała nagrodę Ministra Nauki i Szkolnictwa Wyższego oraz kilkakrotnie nagrodę Rektora.

Od momentu wykazania przez Jubilatkę związków Pomorza w okresie neolitu z obszarem Meklemburgii, Szlezwiku-Holsztyna i wysp duńskich, tematyka relacji ze strefą zachodniobałtycką pozostawała stałym elementem Jej zainteresowań naukowych (Jankowska 1988). Dlatego mimo licznych obowiązków dydaktycznych na uczelni odbywała w tym okresie podróże i staże zagraniczne, podczas których zbierała materiały do przygotowywanej pracy habilitacyjnej poświęconej zagadnieniom neolityzacji północnej części Niziny Środkowoeuropejskiej i południowej Skandynawii. Wśród nich warto wymienić miesięczny pobyt w Lyonie, dwumiesięczne stypendium na Uniwersytecie Christiana-Alberta w Kilonii w 1984 r., a później dwa miesiące 1989 r., które D. Jankowska poświęciła na zapoznanie się ze zbiorami muzeów Hamburga i Hanoweru oraz zbiorami Institut für Ur- und Frühgeschichte Uniwersytetu w Kilonii. Z tamtejszymi naukowcami uczestniczyła w trwających miesiąc badaniach wykopaliskowych na stanowisku torfowym, gdzie zapoznała się ze stosowaną tam specyficzną metodyką prac.

Ukoronowaniem tych wysiłków było zaliczenie przez D. Jankowską 21 marca 1988 r. przed Radą Wydziału Historycznego UAM kolokwium habilitacyjnego na podstawie rozprawy Społeczności strefy poludniowo-zachodniobaltyckiej $w$ dobie neolityzacji. Na zatwierdzenie tego faktu przez Centralną Komisję ds. Kadr Naukowych trzeba było jednak czekać aż do 24 września 1990 r., co wpłynęło na znaczne 
opóźnienie publikacji tej książki (Jankowska 1990). Do dziś jest to jedyne opracowanie w polskiej literaturze przedmiotu tak obszernie i dogłębnie traktujące o mezolicie i wczesnym neolicie zachodniej części basenu Bałtyku, porządkujące dla polskiego czytelnika stosowane tam podziały chronologiczne i kulturowe oraz próbujące wyjaśniać mechanizmy neolityzacji na szeroko zarysowanym tle przyrodniczo-kulturowym.

Już pierwsza książka D. Jankowskiej, zawierająca podstawy wyróżnienia grupy łupawskiej (Jankowska 1980a), została uznana w środowisku europejskim za istotny i trwały wkład do poznania pradziejów obszarów nadbałtyckich. Z jeszcze większym odzewem spotkała się Jej druga praca, która nobilitowała D. Jankowską jako badaczkę neolitu strefy litoralnej Bałtyku. Dzięki niej Jubilatka uznawana jest za liczącą się specjalistkę w zakresie neolitu europejskiego, szczególnie dlatego, że Jej dorobek oparty jest $\mathrm{z}$ jednej strony na efektach wielosezonowych badań terenowych prowadzonych głównie na obszarze Pomorza, z drugiej - na studiach gabinetowych w kraju i za granicą.

Rok 1988 był wyjątkowy dla Jubilatki jeszcze pod innym względem. Wspólnie z Tadeuszem Wiślańskim udało się Jej przygotować i z sukcesem przeprowadzić międzynarodowe sympozjum poświęcone kulturze pucharów lejkowatych w Europie, związanych z nią nowym badaniom terenowym, hipotezom i próbom wyjaśnienia genezy, rozwoju i zaniku tego zjawiska kulturowego. Było to niepowtarzalne spotkanie naukowców z dziewięciu krajów Europy (na 44 uczestników aż 23 przybyło z zagranicy: z Czechosłowacji, Danii, Holandii, Norwegii, NRD, RFN, Szwecji i ZSRR), które odbywało się w urokliwej scenerii hotelu w Dymaczewie koło Poznania, położonego nad otoczonym lasami jeziorem. To właśnie tam, w oddaleniu od miejskiego zgiełku i różnych rozpraszających uwagę atrakcji, przez pięć dni (20-24 września) dyskutowano od rana do wieczora nad różnymi problemami, nie tylko bezpośrednio związanymi z kulturą pucharów lejkowatych. A w dodatku rzecz chyba bez precedensu - organizatorzy przygotowali specjalną wystawę, na której zaprezentowano materiały ceramiczne kultury pucharów lejkowatych z najważniejszych stanowisk $\mathrm{z}$ terenu całej Polski. Część z nich na tę okazję wydobyto z muzealnych magazynów, w tym i takie, które są znane z podręczników archeologii, inne przywieziono prosto $\mathrm{z}$ prowadzonych wtedy badań wykopaliskowych. Wszystkie można było nie tylko oglądać, ale i wziąć do ręki, a przy tym wysłuchać uwag i wyjaśnień od kompetentnych badaczy.

Przygotowanie do druku wygłoszonych w czasie konferencji dymaczewskiej referatów znacznie skomplikowała nagła śmierć T. Wiślańskiego w styczniu $1989 \mathrm{r}$. D. Jankowska pokonała jednak piętrzące się trudności i światło dzienne ujrzała dwutomowa publikacja znana pod tytułem Die Trichterbecherkultur. Neue Forschungen und Hypothesen. Wydarzyło się to w latach 1990-1991, a były to czasy szczególnie trudne $\mathrm{z}$ różnych względów nie tylko dla archeologii, lecz także całego naszego kraju przechodzącego wtedy burzliwe transformacje. W drugim tomie tego wydawnic- 
twa znalazła się ważna praca autorstwa D. Jankowskiej i T. Wiślańskiego (Jankowska, Wiślański 1991), będąca omówieniem najważniejszych problemów badawczych wiążących się z kulturą pucharów lejkowatych na Niżu Polskim, a jednocześnie pewnym podsumowaniem stanu wiedzy, przedstawionym częściowo w wersji opozycyjnej do tzw. modelu kujawskiego, proponowanego przez badaczy związanych z Aleksandrem Kośko (np. Kośko 1981).

Przełom lat 80. i 90. XX w. zakończył w zasadzie aktywność terenową Jubilatki, częściowo z powodu kłopotów zdrowotnych, które ją dotknęły. Za to kilkanaście kolejnych lat poświęciła Ona przede wszystkim sprawom organizacyjnym i dydaktycznym. W 1989 r. została jednym z członków-założycieli Stowarzyszenia Naukowego Archeologów Polskich. Nie pełniła w nim nigdy żadnych funkcji, ale pomimo to zawsze brała czynny udział we wszystkich zebraniach Oddziału SNAP w Poznaniu. Wiele swego czasu, sił i zdrowia poświęciła też macierzystemu Wydziałowi i Instytutowi. W latach 1990-1996 przez dwie kadencje pełniła funkcję prodziekana ds. studenckich na Wydziale Historycznym, przy czym drugą z nich rozpoczęła już jako profesor UAM, ponieważ została mianowana na to stanowisko w październiku $1993 \mathrm{r}$.

Nie były to lata łatwe ani dla uczelni, ani dla władz dziekańskich. Szczególnie pierwsza kadencja przypadła na czas, w którym doszło do podwojenia się liczby studentów. Dokonały się wtedy też istotne zmiany w systemie kształcenia. Trzeba było koordynować nowe formy studiów, takie jak studia licencjackie, dzienne i zaoczne, w Poznaniu i Kaliszu, oraz nowe specjalności i specjalizacje powstające na niemal wszystkich kierunkach Wydziału Historycznego.

Pomimo tych obciążeń D. Jankowska pozostała czynna także na polu naukowym. W latach 90. ukazało się kilka ważnych opracowań Jej autorstwa, z tego część za granicą. Składają się one na pewną całość poświęconą zagadnieniom neolityzacji zachodniej i południowej części basenu Bałtyku (Jankowska 1991, 1994b, 1996, 1997b, 1998a), a więc będącą rozwinięciem problematyki poruszonej w Jej pracy habilitacyjnej. Inne publikacje $\mathrm{z}$ tego okresu można uznać za próby powrotu do badań nad grupą łupawską, choć częściowo z wykorzystaniem nowych materiałów dotyczących chronologii, gospodarki i obrządku pogrzebowego ludności tej jednostki (Jankowska 1994a, 1997a, 1998b, 1999b, 2001a). W tym samym czasie D. Jankowska nie stroniła też od podejmowania nowych tematów badawczych. Była członkiem zespołu konsultantów ratowniczych badań wykopaliskowych na trasie gazociągu Jamał-Europa Zachodnia, a także uczestniczyła w opracowywaniu materiałów neolitycznych pozyskanych $\mathrm{w}$ trakcie tych badań na terenie Wielkopolski. Niestety nie zostały one do tej pory opublikowane.

Sądzę, że pojawienie się źródeł należących do kultur wstęgowych wśród opracowywanych przez D. Jankowską materiałów z badań na gazociągu jamalskim (np. Otorowo, stan. 66) zainspirowało Ją do zajęcia się problematyką początków neolityzacji na terenie Wielkopolski. Co znamienne, ten zwarty tematycznie, choć niewiel- 
ki cykl, świadczący o rozszerzaniu zainteresowań badawczych Jubilatki, został w większości opublikowany w Brnie (Jankowska 1999c, 2000, 2001b).

Po zakończeniu pracy na stanowisku prodziekana Wydziału Historycznego, co nastąpiło w 1996 r., D. Jankowska nie pozostała ani na moment bezczynna. Jeszcze w tym samym roku została ponownie wybrana na wicedyrektora ds. dydaktycznych Instytutu Prahistorii i pełniła tę funkcję aż do 2008 r. (przez cztery kadencje bez przerwy!).

W 1996 r. do programu jednolitych studiów magisterskich w zakresie archeologii w Instytucie Prahistorii wprowadzono specjalizacje. D. Jankowska była współautorką podstawowej wersji tego nowego programu i autorką jego późniejszych korekt, tzw. programu minimum oraz wszystkich programów specjalizacyjnych. Ponadto wielu studentów realizowało programy indywidualne. Wszystko to wymagało opracowania systemu rozliczania studentów. Stopniowo zostało zakończone wdrażanie pełnego cyklu programowego specjalności „archeologia powszechna”, ale jednocześnie rozpoczęto prace nad otworzeniem nowej specjalności - ,archeologia śródziemnomorska". Jubilatka była autorką projektu programu tej specjalności, który po wielu trudnych konsultacjach i uzgodnieniach został zatwierdzony w maju $1998 \mathrm{r}$.

W związku z przejściem Uniwersytetu na międzynarodowy system rozliczania studentów metodą punktów transferowych ETCS prof. Jankowska opracowała potrzebny do tego instytutowy pakiet informacyjny dotyczący studiów archeologicznych, a ponadto uczestniczyła w pracach nad ujednoliceniem punktacji ETCS dla naszego kierunku w całym kraju. Brała też udział w pracach zespołu opracowującego minimum programowe studiów archeologicznych w Polsce, a poza tym pracowała w Uniwersyteckiej Komisji Akredytacyjnej ds. studiów archeologicznych.

D. Jankowskiej nieobca jest też działalność społeczna - wielokrotnie angażowała się $\mathrm{w}$ różne przedsięwzięcia na terenie Uniwersytetu i poza nim. Była m.in. członkiem Komisji Dyscyplinarnej dla studentów, Wydziałowej Komisji Dydaktycznej, Komisji Rektorskiej ds. Collegium Polonicum w Słubicach i członkiem Rady Programowej Stacji Monitoringu Środowiska Przyrodniczego w Białej Górze koło Międzyzdrojów, a ponadto radną Osiedla Nowe Winogrady Północ i członkiem zarządu Poznańskiej Spółdzielni Mieszkaniowej Winogrady. Nie unikała też nigdy zaangażowania politycznego. Początkowo działała w Związku Młodzieży Socjalistycznej, później przez wiele lat była członkiem Stronnictwa Demokratycznego. Od 2011 r. należy do Akademickiego Klubu Obywatelskiego im. Prezydenta Lecha Kaczyńskiego w Poznaniu, a w wyborach samorządowych, które odbyły się w listopadzie 2014 r., kandydowała do Rady Miasta Poznania z listy partii Prawo i Sprawiedliwość.

Ostatnie lata działalności D. Jankowskiej na uczelni wiążą się ze stopniowo ograniczaną, ze względu na Jej wiek i stan zdrowia, liczbą obciążeń dydaktycznych. Nadal jednak publikuje, nawiązując w swej twórczości do wcześniej prowadzonych 
badań wykopaliskowych (Galiński, Jankowska 2006) i studiów nad obrządkiem pogrzebowym kultury pucharów lejkowatych (Jankowska 2005, 2010). Podejmuje się też różnego rodzaju podsumowań z perspektywy swego doświadczenia (Jankowska 2007, 2009b).

Na zakończenie tego zarysu postaci prof. Dobrochny Jankowskiej nie można pominąc jeszcze jednego nurtu zaznaczającego się w Jej twórczości. To wspomnienia o zmarłych, a znanych Jej osobiście, wybitnych osobistościach polskiej, niemieckiej i czeskiej archeologii. Naturalną koleją rzeczy w ostatnich latach jest ich więcej. Pierwszą tak uhonorowaną przez Nią osobą był nieodżałowanej pamięci Kazimierz Siuchniński - „uczony i wychowawca”, jak Go nazwała w 25. rocznicę śmierci (Jankowska 1981b, 2005a). Drugą osobą, również uważaną przez Jubilatkę za mistrza, był Wojciech Kóčka (Jankowska 2009a). Trzy inne teksty o podobnym charakterze D. Jankowska poświęciła ludziom, którzy byli właściwie jej rówieśnikami, z którymi przez wiele lat blisko współpracowała, wymieniała się doświadczeniami i uczestniczyła w ich badaniach wykopaliskowych. To Pavel Koštuřík z Brna (Jankowska 1999a), Erika Nagel ze Schwerina (Jankowska 2003a) oraz Jürgen Hoika ze Szlezwiku (Jankowska 2009c).

W ostatnich słowach swego wspomnienia o K. Siuchnińskim Jubilatka napisała: „Są uczeni, których wielkość wyraża się w ich dorobku pisarskim i tacy, którzy są wielcy poprzez swoich uczniów, których ukształtowali, zainspirowali i pozwolili się im swobodnie rozwijać i iść własną drogą. Pierwsi figurują w encyklopediach, drudzy żyją w ludzkich sercach; jest ich niewielu, ale to właśnie dzięki nim dokonuje się prawdziwy postęp" (Jankowska 2005a, s. 12). Myślę, że gdyby On żył, byłby dumny z takiej uczennicy.

\section{BIBLIOGRAFIA}

Indycka E., Wierzbicki J.

1993 Materiały kultury pucharów lejkowatych z terenu kopalni surowców mineralnych w Poganicach, woj. Słupsk, stanowisko 4. W: D. Jankowska, J. Wierzbicki (red.), Kopalnia surowców mineralnych kultury pucharów lejkowatych w Poganicach woj. Stupsk, stanowisko 4 (strefa 10) (Materiały do badań nad grupą łupawską kultury pucharów lejkowatych 3, s. 75-116). Poznań: Instytut Prahistorii Uniwersytetu im. Adama Mickiewicza.

Jankowska D.

1967 Odkrycia. Materiaty Zachodniopomorskie, 11(1965), s. 889-935.

Jankowska D.

1968 Sprawozdanie z działalności Muzeum w Szczecinku w 1966 roku. Materiały Zachodniopomorskie, 12(1966), s. 830-831.

Jankowska D.

1969 Cmentarzysko ludności kultury pomorskiej w Szczecinku, stanowisko 5. W: F.J. Lachowicz (red.), Sprawozdania z badań archeologicznych prowadzonych na terenie woje- 
wództwa koszalińskiego w latach 1967-1968 (s. 65-74). Koszalin: Wydział Kultury Prezydium Wojewódzkiej Rady Narodowej i Wojewódzki Konserwator Zabytków w Koszalinie.

Jankowska D.

1971 Wczesnośredniowieczne osady typu wiejskiego na Nizinie Wielkopolskiej. Studia i Materiaty do Dziejów Wielkopolski i Pomorza, 10(2), s. 11-42.

Jankowska D.

1972 Archeologiczna praktyka terenowa i jej funkcje dydaktyczno-wychowawcze. Neodidagmata, 4, s. 189-196.

Jankowska D.

1973 Sprawozdanie z prac wykopaliskowych na osadzie kultury pucharów lejkowatych w Poganicach, pow. Słupsk, stanowisko 4, w 1971 roku. Koszalińskie Zeszyty Muzealne, 2(1972), s. 229-236.

Jankowska D.

1974 O metodzie badania grobowców megalitycznych. W: F.J. Lachowicz (red.), Studia Archaeologica Pomeranica (s. 79-91). Koszalin: Muzeum Archeologiczno-Historyczne.

Jankowska D.

1975a Cmentarzysko kultury pucharów lejkowatych w Łupawie, pow. Słupsk (stanowisko 15). Sprawozdania Archeologiczne, 27, s. 27-42.

Jankowska D.

1975b Sprawozdanie z prac wykopaliskowych na stanowisku 4 w Poganicach, pow. Słupsk, w 1973 roku. Koszalińskie Zeszyty Muzealne, 4(1974), s. 3-12.

Jankowska D.

1976 Die kulturellen Zusammenhänge zwischen der Trichterbecherkultur und Kugelamphorenkultur im Gebiet von Pommern. Zeitschrift für Archäologie, 10, s. 21-22.

Jankowska D.

1977 Relacje między kulturą pucharów lejkowatych a amfor kulistych na Pomorzu. Pomorania Antiqua, 7, s. 9-15.

Jankowska D.

1980a Kultura pucharów lejkowatych na Pomorzu Środkowym. Grupa tupawska (Seria Archeologiczna 17). Poznań: Wydawnictwo Naukowe Uniwersytetu im. Adama Mickiewicza.

Jankowska D.

1980b Zabytek sztuki romańskiej z Wojnowic. Slavia Antiqua, 26(1979), s. 335-339.

Jankowska D.

1981a Kultura pucharów lejkowatych na Pomorzu Środkowym (grupa łupawska) ze szczególnym uwzględnieniem jej obrządku pogrzebowego. W: T. Wiślański (red.), Kultura pucharów lejkowatych w Polsce (studia i materiaty) (s. 119-135). Poznań: Polska Akademia Nauk, Oddział w Poznaniu i Leszczyńskie Towarzystwo Kulturalne w Lesznie.

Jankowska D.

1981b Wspomnienie o Kazimierzu Siuchnińskim. Koszalińskie Zeszyty Muzealne, 11, s. $129-131$.

Jankowska D.

1983 Kultury pucharów lejkowatych i amfor kulistych na Pomorzu. W: T. Malinowski (red.), Problemy epoki kamienia na Pomorzu (s. 147-166). Słupsk: Wyższa Szkoła Pedagogiczna i Muzeum Pomorza Środkowego.

Jankowska D.

1984 Z badań nad najstarszym osadnictwem w rejonie dolnej Odry. Materialy Zachodniopomorskie, 26(1980), s. 19-38. 
Jankowska D.

1985 Stan badań nad kulturą ceramiki sznurowej na Pomorzu. Folia Praehistorica Posnaniensia, 1(1984), s. 63-72.

Jankowska D.

1988 On the question of contacts between Pomerania and the West Baltic zone during the Stone Age. Folia Praehistorica Posnaniensia, 3(1987), s. 73-81.

Jankowska D.

1990 Spoleczności strefy poludniowo-zachodniobaltyckiej $w$ dobie neolityzacji. Poznań: Wydawnictwo Naukowe Uniwersytetu im. Adama Mickiewicza.

Jankowska D.

1991 Einige Probleme des pommerschen Neolithikums vor dem Hintergrund der westlichen Ostsee-Zone. W: K. Jennbert, L. Larsson, R. Petré, B. Wyszomirska-Werbart (red.), Regions and Reflections. In Honour of Märta Strömberg (s. 27-33). Lund: Almqvist \& Wiksell International.

Jankowska D.

1994a Frühneolithische Elemente in der mittelpommerschen Łupawa-Gruppe der Trichterbecherkultur. W: J. Hoika, J. Meurers-Balke (red.), Beiträge zur frühneolithischen Trichterbecherkultur im westlichen Ostseegebiet, 1. Internationales Trichterbechersymposium in Schleswig (s. 137-154). Neumünster: Wachholz Verlag.

Jankowska D.

1994b Umweltbedingungen der Neolithisierung im südlichen Ostseegebiet. Bodendenkmalpflege in Mecklenburg-Vorpommern, 41(1993), s. 7-18.

Jankowska D.

1996 Neolit Pomorza Zachodniego - nie rozwiązany problem badawczy. W: E. Wilgocki,

P. Krajewski, M. Dworaczyk, D. Kozłowska (red.), 50 lat archeologii polskiej na Pomorzu Zachodnim (s. 11-25). Szczecin: Stowarzyszenie Naukowe Archeologów Polskich, Oddział w Szczecinie.

Jankowska D.

1997a Megalithic Graves in the Łupawa-Group of the Funnel Beaker Culture. W: D. Król (red.), The Baltic Sea-Coast Landscapes Seminar, Session No. 1. The Built Environment of Coast Areas during the Stone Age. A symposium at the Centenary of Archaeological Excavations at Rzucewo (Rzucewo-Gdańsk) 4-9 October 1994 (s. 208-213). Gdańsk: Regionalny Ośrodek Studiów i Ochrony Środowiska Kulturowego.

Jankowska D.

1997b The Funnel Beaker Culture in Pomerania. W: D. Król (red.), The Baltic Sea-Coast Landscapes Seminar, Session No. 1. The Built Environment of Coast Areas during the Stone Age. A symposium at the Centenary of Archaeological Excavations at Rzucewo (Rzucewo-Gdańsk) 4-9 October 1994 (s. 108-118). Gdańsk: Regionalny Ośrodek Studiów i Ochrony Środowiska Kulturowego.

Jankowska D.

1998a Environmental Conditions during the Neolithisation of Pomerania. W: M. Zvelebil, L. Domańska, R. Dennell (red.), Harvesting the Sea, Farming the Forest: The Emergence of Neolithic Societies in the Baltic Region and Adjacent Areas (Sheffield Archaeological Monographs 10, s. 121-128). Sheffield: Sheffield Academic Press.

Jankowska D.

1998b Neolityczne spichrze z obszaru ziem polskich. Sbornik praci Filozofické fakulty Brněnské univerzity, Řada archeologická (M), 46(2), s. 113-124.

Jankowska D.

1999a Dr hab. Pavel Koštuřik (1946-1998). Folia Praehistorica Posnaniensia, 9, s. 260-261. 
Jankowska D.

1999b Megalithik und kujawische Gräber. W: K.W. Beinhauer, G. Cooney, C.E. Guksch, S. Kus (red.), Studien zur Megalithik. Forschungsstand und ethnoarchäologische Perspektiven (s. 215-226). Weißbach: Verlag Beier \& Beran.

Jankowska D

1999c Remarks on the Study of Consumption in the Communitives of the Late Band Pottery Culture (LPC) and the Corded Ware Culture Inhabiting Polish Territories (A Comparative Study). W: D. Jankowska, M. Krenz-Niedbała, J. Piontek, J. Wierzbicki, Biological and Cultural Consequences of the Transition to Agriculture in Central Europe (s. 27-44). Poznań: Instytut Antropologii Uniwersytetu im. Adama Mickiewicza.

Jankowska D.

$2000 \quad$ Z badań nad osadnictwem późnowstęgowym w Wielkopolsce. Sborník prací Filozofické fakulty Brněnské univerzity. Řada archeologická (M), 48(4;1999), s. 81-101.

Jankowska D.

2001a Elementy „leśne” w neolicie Pomorza. W: J. Czebreszuk, M. Kryvalcevič, P. Makarowicz (red.), Od neolityzacji do początków epoki brązu. Przemiany kulturowe w międzyrzeczu Odry i Dniepru między VI i II tys. przed Chr. (s. 85-97). Poznań: Wydawnictwo Poznańskie.

Jankowska D.

2001b Najstarsze osadnictwo neolityczne w Wielkopolsce. W: Otázky neolitu a eneolitu našich zemí. Sborník referátů z 18. pracovního zasedání badatelì pro výzkum neolitu a eneolitu Čech, Moravy a Slovenska, Mostkovice 14.-17. zář 1999 (Pravěk. Supplementum 8, s. 25-39). Brno: Ústav archeologické památkové péče.

Jankowska D.

2003a Dr Erika Nagel (31.12.1943 - 24.07.1999). Folia Praehistorica Posnaniensia, 10-11, s. $398-400$.

Jankowska D.

2003b Wczesnośredniowieczne grodzisko w Łupawie na Pomorzu Środkowym. W: J. Olczak (red.), Studia z archeologii, historii i historii architektury (Archaeologia Historica Polona 13, s. 207-220). Toruń: Uniwersytet Mikołaja Kopernika, Uniwersyteckie Centrum Archeologii Średniowiecza i Nowożytności.

Jankowska D.

2005a Kazimierz Siuchniński - uczony i wychowawca. Folia Praehistorica Posnaniensia, 13/14, s. 9-13.

Jankowska D.

2005b O pochodzeniu pomorskich grobowców bezkomorowych kultury pucharów lejkowatych. Folia Praehistorica Posnaniensia, 13/14, s. 133-145.

Jankowska D.

2007 Miejsce nauk przyrodniczych w polskich studiach nad neolitem w latach 1939-1989. W: J. Lech (red.), Pót wieku z dziejów archeologii polskiej (1939-1989) (s. 265-276). Warszawa: Wydawnictwo Naukowe PWN.

Jankowska D.

2009a Profesor dr hab. Wojciech Kóčka - wspomnienie po latach. Folia Praehistorica Posnanienisa, 15, s. 11-21.

Jankowska D.

2009b Rozwój badań nad epoką kamienia na Pomorzu w ostatnim 25-leciu. W: M. Fudziński, H. Paner (red.), Aktualne problemy epoki kamienia na Pomorzu (s. 23-36). Gdańsk: Muzeum Archeologiczne. 
Jankowska D.

2009c Z najnowszej historii archeologii. Dr Jürgen Hoika (4 VI 1941 - 1 II 2005). Folia Praehistorica Posnanienisa, 15, s. 453-455.

Jankowska D.

2010 W kwestii obrządku pogrzebowego KPL na ziemiach polskich - stare i nowe problemy. Sborník praci Filozofické fakulty Brněnské univerzity. Řada archeologická (M), 14-15 (2009-2010), s. 263-275.

Galiński T., Jankowska D.

2006 Bolków 1. Stanowisko z końca paleolitu i początków mezolitu nad jeziorem Świdwie na Pomorzu Zachodnim. Materiaty Zachodniopomorskie, NS 2-3(1), s. 79-176.

Jankowska D., Kośko A.

1974 Sprawozdanie z badań nad osadnictwem kultury pucharów lejkowatych na Pomorzu Środkowym w 1972 r. Koszalińskie Zeszyty Muzealne, 3(1973), s. 30-46.

Jankowska D., Kośko A., Siuchniński K., Quitta H., Kohl G.

1979 Untersuchungen zur Chronologie der neolithischen Kulturen im Polnischen Tiefland. Zeitschrift für Archäologie, 13/2, s. 219-240.

Jankowska D., Wiślański T.

1991 Trichterbecherkultur im Polnischen Tiefland - die Wichtigsten Forschungsprobleme. W: D. Jankowska (red.), Die Trichterbecherkultur. Neue Forschungen und Hypothesen. Material des Internationalen Symposiums Dymaczewo, 20-24 September 1988 (Teil II, s. 53-65). Poznań: Instytut Prahistorii UAM i Zakład Archeologii Wielkopolski IHKM PAN.

Kośko A.

1981 Udziat poludniowo-wschodnioeuropejskich wzorców kulturowych $w$ rozwoju niżowych społeczeństw kultury pucharów lejkowatych. Grupa mątewska (Seria Archeologia 14, Materiały do syntezy pradziejów Kujaw 4). Poznań: Wydawnictwo Naukowe Uniwersytetu im. Adama Mickiewicza.

Pankowski A.

1990 Cmentarzysko kurhanowe ludności kultury łużyckiej w Łupawie, województwo słupskie. Materiały Zachodniopomorskie, 35/36(1989/1990), s. 49-74.

Świderski W., Wierzbicki J.

1990 Osada ludności kultury pucharów lejkowatych w Poganicach, woj. Stupsk, gm. Potęgowo, stanowisko 4 (strefa 2) (Materiały do badań nad grupą łupawską kultury pucharów lejkowatych 1). Poznań: Instytut Prahistorii Uniwersytetu im. Adama Mickiewicza.

Weber A.

1983 Studia nad obrzadkiem pogrzebowym grupy tupawskiej kultury pucharów lejkowatych (Seria Archeologiczna 21). Poznań: Wydawnictwo Naukowe Uniwersytetu im. Adama Mickiewicza.

Wierzbicki J.

1992 Cmentarzysko kultury pucharów lejkowatych w Lupawie, woj. Stupsk, stanowisko 2. Obrzadek pogrzebowy grupy tupawskiej (Materiały do badań nad grupą łupawską kultury pucharów lejkowatych 2). Poznań: Instytut Prahistorii Uniwersytetu im. Adama Mickiewicza. 